\title{
Penerapan Model Problem Solving Berbantu Media Kalkulator Ajaib untuk Meningkatkan Kemampuan Pemahaman Konsep Operasi Hitung
}

\author{
Akhsin Amrulloh ${ }^{1}$, Sukamto ${ }^{2}$, Husnul Hadi ${ }^{3}$ \\ ${ }^{1,2,3}$ Pendidikan Sekolah Dasar, Fakultas IImu Pendidikan, Universitas PGRI Semarang \\ e-mail: akhsinamrulloh@gmail.com
}

\begin{abstract}
ABSTRAK
Permasalahan yang dihadapi dalam pembelajaran matematika di kelas V Sd N Wonolopo 02 Semarang adalah rendahnya dalam kemampuan pemahaman operasi hitung dan pemecahan masalah matematika pada siswa, sehingga siswa kurang memahami materi yang disampaikan. Oleh karena itu penelitian ini bertujuan untuk mendeskripsikan penerapan model problem solving berbantu media kalkulator ajaib untuk meningkatkan kemampuan pemahaman konsep operasi hitung pada siswa kelas V SD N Wonolopo 02 Semarang Tahun Ajaran 2018/2019. Jenis penelitian ini adalah kuantitatif dengan desain Pre-Experimental Designs (nondesigns) dengan desain penelitian OneGroup Pretest-Posttest Design. Populasi dalam penelitian ini adalah semua siswa kelas $\mathrm{V}$ yang berjumlah 36 siswa. Sampel yang diambil adalah semua siswa kelas $V$ yang berjumlah 36 siswa, dengan menggunakan teknik Nonprobability Sampling dengan jenis teknik sampling jenuh. Nilai pemahaman konsep operasi hitung diperoleh dari nilai pretest dan posttest. Hasil penelitian ini diperoleh dengan melakukan analisis data awal, uji normalitas dengan uji lilliefors, analisis data akhir dengan uji t-test dan uji $\mathrm{N}$-Gain. Berdasarkan pada analisis data akhir yang telah dilakukan perhitungan uji $t$-test diperoleh $t_{\text {hitung }}>t_{\text {tabel }}$ yaitu 4,36 $>2,021$ maka hipotesis dapat diterima, dan perhitungan dengan uji $\mathrm{N}$-Gain diperoleh 0,36 dengan kategori sedang. Dapat disimpulkan bahwa model problem solving berbantu media kalkulator ajaib efektif untuk meningkatkan kemampuan konsep operasi hitung pada siswa kelas V SD N Wonolopo 02 Semarang. Berdasarkan hasil penelitian ini saran yang dapat disampaikan adalah supaya model pembelajaran problem solving berbantu media kalkulator ajaib dapat digunakan sebagai alternative guru dalam mengajar.
\end{abstract}

Kata kunci: Model Problem Solving, Media Kalkulator Ajaib, Pemahaman Konsep, Operasi Hitung

\section{ABSTRACT}

The problem faced in mathematics learning in class $\mathrm{V}$ of Sd N Wonolopo 02 Semarang is the low ability to understand counting operations and solving mathematical problems in students, so that students do not understand the material presented. Therefore this study aims to describe the application of a media-assisted problem solving problem calculator to increase the ability to understand the concept of counting operations in fifth grade students of SD N Wonolopo 02 Semarang Academic Year 2018/2019. This type of research is quantitative with the design of Pre-Experimental Designs (nondesigns) with the research design of One-Group Pretest-Posttest Design. The population in this study were all students of class $V$ which numbered 36 students. The samples taken were all students of class V, amounting to 36 students, using the Nonprobability Sampling technique with a type of saturated sampling technique. The value of understanding the calculated operation concept is obtained from the pretest and posttest values. The results of this study were obtained by conducting preliminary data analysis, normality test with lilliefors test, analysis of final data with t-test and $\mathrm{N}$-Gain test. Based on the final data analysis that has been calculated the t-test is obtained tcount $>t$ table is $4.36>2.021$ then the hypothesis can be accepted, and the calculation with the N-Gain test is obtained 0.36 with the medium category. It can be concluded that the media-assisted problem solving model is a miraculous calculator to improve the ability of the calculation operation concept in fifth grade students of SD N Wonolopo 02 Semarang. Based on the results of this study the suggestions that can be conveyed are that the media-assisted problem solving learning model of the magic calculator can be used as an alternative teacher in teaching.

Keywords: Model Problem Solving, Magic Media Calculator, Understanding Concepts, Calculating Operations 


\section{Pendahuluan}

Peningkatan mutu pendidikan di indonesia saat ini sangat penting. Hal ini dikarenakan dengan adanya pendidikan melalui potensi diri, kepribadian, kecerdasan, akhlak mulia, serta keterampilan pada diri anak dapat terasah. Hal ini sesuai dengan Undang - Undang RI No. 20 Tahun 2003 pasal 1 ayat 1 tentang Sistem Pendidikan Nasional yang menyatakan bahwa:

"Pendidikan adalah usaha sadar dan terencana untuk mewujudkan suasana belajar dan proses pembelajaran agar peserta didik secara aktif mengembangkan potensi dirinya untuk memiliki kekuatan spiritual keagamaan, pengendalian diri, kecerdasan, akhlak mulia, serta keterampilan yang diperlukan dirinya, masyarakat, bangsa dan negara".

Pendidikan saat ini menuntut guru tidak hanya menguasai kelas, menguasai materi tetapi guru juga harus dituntut untuk bisa kreatif dan inovatif. Hal ini dikarenakan dengan karakteristik siswa yang cepat bosan dan selalu ingin bermain ketika pembelajaran berlangsung. Serta faktor penyampaian materi yang kurang menarik siswa. Bahan ajar yang digunakan oleh guru adalah buku saja serta media yang tidak bervariasi dan menarik minat siswa untuk belajar. Akibatnya siswa kesulitan memahami materi pembelajaran yang dijelaskan oleh guru. Siswa terkadang melakukan kegiatan yang tidak berhubungan dengan pembelajaran misalnya berbicara dengan teman sebangkunya, mengganggu temannya,bermain dengan mainan yang dibawa. Kondisi belajar mengajar yang tidak inovatif dapat mengakibatkan kemampuan pemahaman konsep siswa yang tidak optimal terutama pada pelajaran matematika.

Menurut Arief Kristiyawan (2009:3) faktor yang menyebabkan rendahnya pemahaman konsep siswa dalam belajar matematika adalah kegiatan pembelajaran yang terpusat pada guru. Oleh karena itu, guru diharapkan utuk kreatif dalam menggunakan model pembelajaran agar siswa tertarik mengikuti pembelajaran, karena model pembelajaran yang menyenangkan mampu mengembangkan pemahaman konsep siswa.

Menurut Ahmad Susanto (2016: 186), pembelajaran matematika adalah suatu proses belajar mengajar yang dibangun oleh guru untuk mengembangkan kreativitas berpikir siswa yang dapat meningkatkan kemampuan berpikir siswa, serta dapat meningkatkan kemampuan mengkonstruksi pengetahuan baru sebagai upaya meningkatkan penguasa yang baik terhadap materi matematika.

Belajar matematika merupakan suatu syarat cukup untuk melanjutkan pendidikan ke jenjang berikutnya. Karena dengan belajar matematika, kita akan belajar bernalar secara kritis, kreatif dan aktif. Matematika merupakan ide-ide abstrak yang berisi sinmbol-simbol, maka konsep-konsep matematika harus dipahami terlebih dahulu sebelum memanipulasi simbol-simbol.

Pada mata pelajaran matematika yang ada di Sekolah Dasar peserta didik diajarkan untuk mengenal konsep matematika yang bersifat verbal yang berkaitan dengan bilangan. Kemampuan siswa dalam memahami konsep dasar perkalian dan pembagian pecahan biasa maupun pecahan campuran menjadi dasar dalam pembelajaran matematika sehingga dalam pemahaman konsep operasi hitung siswa dapat hal yang penting untuk dikembakan dan ditingkatkan oleh guru dalam pembelajaran matematika. Salah satu materi yang diajarkan di kelas $\mathrm{V}$ Sekolah Dasar adalah pecahan yang mempunyai kompetensi dasar melakukan penjumlahan, pengurangan, perkalian dan pembagian berbagai bentuk pecahan.

Berdasarkan data hasil wawancara kepada Ibu Tary guru kelas V SD N Wonolopo 02 Semarang mengenai kemampuan pemahaman konsep operasi hitung pecahan yang mengungkapkan beberapa fakta. Fakta yang ditemukan antara lain: (1) Pelaksanaan pembelajaran matematika yang dilakukan oleh guru kelasnya belum menggunakan model pembelajaran yang inovatif, (2) Guru hanya menggunakan model ceramah, diskusi dan tanya jawab, (3) Belum menggunakan media pembelajaran yang inovatif. Dalam pemahaman konsep operasi hitung peserta didik sulit untuk menangkap penjelasan yang 
disampaikan oleh guru yang disebabkan karena peserta didik kurangnya pengawasan dari orang tua sehingga peserta didik mengalami kekurangan dalam proses belajar dikelas. Kualitas hasil belajar peserta didik dalam operasi hitung pecahan yang dicapai kurang optimal. Dapat diperoleh data sebagai berikut: siswa kelas V, dari 36 siswa terdapat 14 siswa (40\%) yang nilainya mencapai Kriteria Ketuntasan Minimal (KKM) dan 22 siswa $(60 \%)$ yang nilainya tidak mencapai Kriteria Ketuntasan Minimal (KKM).

Berdasarkan uraian masalah yang ada di SD N Wonolopo 02 Semarang diatas, maka tentunya perlu diberikan tindakan penanganan yang tepat agar masalah berkaitan dengan pemahaman konsep operasi hitung pecahan pada siswa bisa berkurang dan membuat siswa memahami konsep operasi hitung dengan baik serta siswa dapat meningkatkan hasil belajar mereka mengenai operasi hitung pecahan. Usaha sadar dan terencana dalam membantu meningkatkan pemahaman operasi gitung pada siswa, dapat dilakukan dengan memberikan pengajaran di kelas dengan menggunakan model problem solving atau biasa disebut pembelajaran pemecahan masalah.

Menurut (Drs. Syaiful Bahri Djamarah dan Drs. Aswan Zain, 2006) "Problem solving adalah belajar memecahkan masalah. Pada tingkat ini para anak didik belajar merumuskan memecahkan masalah, memberikan respons terhadap rangsangan yang mengambarkan atau membangkitkan situasi poblematik, yang mempergunakan berbagai kaidah yang telah dikuasai".

Peneliti memilih model problem solving karena model tersebut sesuai dengan permasalahan yang dialami siswa. Model problem solving berbasis pada pemecahan masalah, dengan memberikan permasalahan yang ada di kehidupan nyata sebagai sebuah konteks untuk para siswa dapat berlatih tentang bagaimana cara berpikir cerdas dan kritis, serta dapat belajar memahami sebuah permasalahan dan menganalisis bagaimana cara menyelesaikan permasalahan tersebut dengan tepat. Peneliti memilih model ini dikarenakan model problem solving masih jarang digunakan, salah satunya di SD N Wonolopo 02 Semarang yang belum menggunakan model tersebut.

Namun, dalam setiap pembelajaran pasti ada sisi kelebihan dan kekurangan begitu juga didalam metode pembelajaran problem solving mempunyai beberapa kelebihan dan kekurangan menurut Hamdani (2011), diantaranya adalah: Kelebihan Model Pembelajaran Problem Solving (1) melatih siswa untuk menghadapi problema atau situasi yang timbul secara spontan, ( 2) siswa menjadi aktif dan berinisiatif serta bertanggung jawab, (3) pendidikan di sekolah relevan dengan kehidupan, dan (4) sukar sekali menentukan masalah yang benar-benar cocock dengan tingkat kemampuan siswa Kekurangan Model Pembelajaran Problem Solving: (1) memerlukan waktu yang lama, artinya memerlukan alokasi waktu yang lebih panjang dibandingkan dengan metode pembelajaran yang lain, (2) siswa yang pasif dan malas akan tertinggal, dan (3) sukar sekali untuk mengorganisasikan bahan pelajaran.

Salah satu media yang sesuai digunakan untuk penyampaian materi dengan model problem solving adalah media kalkulator ajaib karena media ini dapat digunakan untuk menghitung perkalian dan pembagian oleh siswa. Dengan media kalkulator ajaib dapat membuat siswa lebih aktif, rasa ingin tahu lebih muncul untuk melakukan cara berhitung dengan media tersebut, sehingga pembelajaran akan terasa lebih inovatif dan tidak membosankan.

Dengan diterapkannya model problem solving berbantu media kalkulator ajaib, diharapkan siswa dapat lebih mudah memahami konsep operasi hitung dan mengusai kemampuan berhitung melalui kegiatan pembelajaran serta dapat mengatasi masalah yang dialami. Berdasarkan latar belakang di atas maka peneliti mengambil judul "Penerapan model problem solving berbantu media kalkulator ajaib untuk meningkatkan kemampuan pemahaman konsep operasi hitung pada siswa". 


\section{Metode}

Pelaksanaan kegiatan penelitian pembelajaran dilaksanakan pada semester II di SD N Wonolopo 02 Semarang. Pada penelitian ini metode penelitian yang digunakan adalah penelitian kuantitatif. Metode penelitian kuantitatif dapat diartikan sebagai metode penelitian yang digunakan untuk meneliti populasi atau sampe, teknik pengambilan sampel pada umumnya dilakukan secara random, pengumpulan data menggunakan instrumen penelitian, analisis data bersifat statistik (Sugiyono, 2017: 13).

Sampel dalam penelitian ini adalah seluruh kelas V SD N Wonolopo 02 Semarang yang berjumlah 36 siswa. Penelitian ini menggunakan teknik Nonprobability Sampling karena semua anggota populasi dipilih menjadi sampel.

Penelitian ini menggunakan desain penelitian Pre-Experimental Designs (nondesigns) dalam bentuk One-Group Pretest-Posttest Design. Karena terdapat pretest sebelum diberikan perlakuan, yang selanjutnya diberikan perlakuan yaitu pembelajaran dengan menggunakan model pembelajaran problem solving, kemudian dilakukan posttest. Dengan demikian hasil perlakuan dapat diketahui lebih akurat, karena dapat membandingkan dengan keadaan sebelum diberi perlakuan. Desain ini dapat digambarkan seperti berikut:

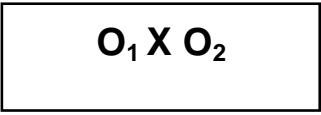

(Sugiyono, 2017: 111).

Keterangan:

O1 = Nilai pretest (sebelum diberi perlakuan) yang dilakukan satu kali untuk mengukur variabel terikat

O2 = Nilai posttest (setelah diberi perlakuan) yang dilakukan satu kali untuk mengukur variabel bebas.

$\mathrm{X}=$ Perlakuan (treatment). Dilakukan dengan Menggunakan model pembelajaran problem solving berbantu media kalkulator ajaib pada mats pelajaran matematika materi perkalian dan pembagian pecahan

Teknik pengumpulan data yang digunakan dalam penelitian ini yaitu tes, observasi, wawancaradan dokumentasi. Instrumen tes berupa pretest dan posttest. Pretest dan posttest ini dilakukan dengan menggunakan soal berupa 10 soal essai/uraian.

Uji analisis data dalam penelitian ini menggunakan: 1) uji normalitas untuk mengetahui sampel dari populasi berdistribusi normal atau tidak (Sudjana, 2005: 466), 2) ) uji t dapat dilakukan setelah diketahui hasil pretest dan posttest. Untuk mengujinya peneliti menggunakan uji t-test untuk mengetahui perbedaan hasil antara yang diberi perlakuan dengan yang tidak diberi perlakuan (Soegeng dan suharno, 2010: 62), dan uji N-Gain dilakukan setelah diketahui hasil pretest dan posttest. Untuk mengujinya peneliti menggunakan N-Gain untuk mengetahui tingkat kriterianya setelah diberi perlakuan.

\section{Hasil dan Pembahasan}

Peneliti mengambil judul "Penerapan Model Problem Solving Berbantu Media Kalkulator Ajaib Untuk Meningkatkan Kemampuan Pemahaman Konsep Operasi Hitung Pada Siswa" dengan tujuan meningkatkan pemahaman operasi hitung materi perkalian dan pembagian pecahan pada siswa kelas V SD N Wonolopo 02 Semarang. Data awal berupa hasil pretest menunjukan bahwa masih banyak yang belum mencapai KKM terdapat 5 siswa yang sudah mencapai KKM dan 31 siswa yang belum mencapai KKM dengan nilai rata-rata pretest 47,17 . Selanjutnya peneliti memberikan perlakuan berupa model problem solving berbantu media kalkulator ajaib. Setelah diberikan perlakuan peneliti melakukan posttest yang mana hasilnya terdapat perubahan pada pemahaman konsep operasi hitung perkalian 
dan pembagian pecahan. Hasil posttest tersebut menunjukkan 8 siswa belum mencapai KKM dan 28 siswa sudah mencapai KKM dengan nilai rata-rata posttest 66,50. Dari hasil nilai pretest dan nilai posttest ini menunjukan bahwa ada peningkatan terhadap hasil pemahaman operasi hitung siswa sesudah perlakuan dengan rata-rata sebesar 19,33.

Berdasarkan analisis tersebut maka dapat dikatakan ada perbedaaan yang belum diberi perlakuan dengan yang sudah diberi perlakuan dengan model problem solving berbantu media kalkulator ajaib, untuk lebih jelasnya dapat dilihat pada gambar 2 :

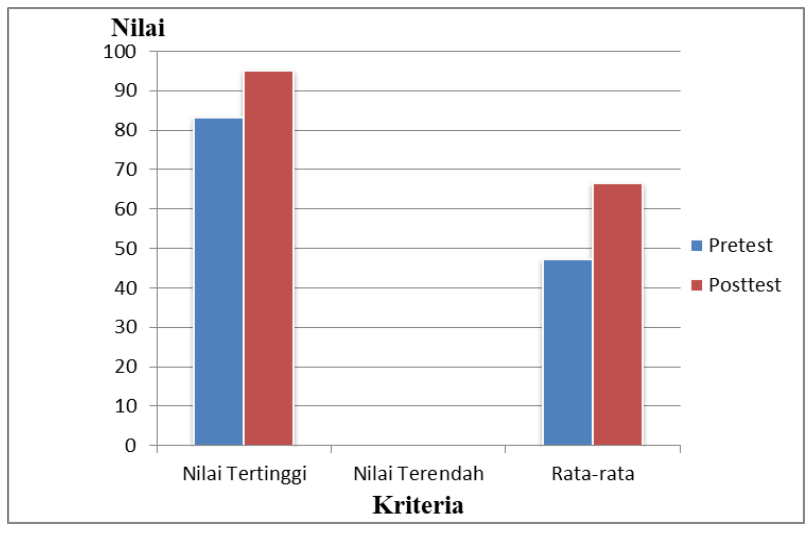

Gambar 1. diagram hasil nilai pretest dan posttest

Berdasarkan diagram 1 ada perbedaaan rata-rata pretest dan posttest siswa kelas $\mathrm{V}$ SD N Wonolopo 02 Semarang. Hal ini menunjukkan bahwa siswa yang diberi perlakuan penggunaan model problem solving berbantu media kalkulator ajaib mengalami peningkatan pemahaman konsep operasi hitung pecahan. Hasil nilai pada penelitian ini yang dijadikan sebagai data akhir penelitian yaitu nilai posttest. Selanjutnya dilakukan pengujian data dengan uji normalitas yang dapat dilihat pada tabel 1 dan tabel 2.

Tabel 1. Uji Normalitas Awal

\begin{tabular}{llll}
\hline Kelas & $\mathrm{L}_{\text {tabel }}$ & $\mathrm{L}_{0}$ & Keterangan \\
\hline Responden & 0,19 & 0,12 & Normal \\
\hline
\end{tabular}

Berdasarkan Tabel 1. perhitungan uji normalitas awal menggunakan nilai pretest diketahui setelah mencari harga Ltabel dari nilai kritis uji lilliefors dengan taraf signifikan $a=$ $5 \%$ dan $n=36$ diperoleh Ltabel $=0,19$. Sehingga dapat disimpulkan bahwa $L 0<$ Ltabel yaitu: $0,12<0,19$ maka HO diterima. Hal ini berarti sampel berasal dari populasi yang berdistribusi normal.

Tabel 2. Uji Normalitas Akhir

\begin{tabular}{llll}
\hline Kelas & $\mathrm{L}_{\text {tabel }}$ & $\mathrm{L}_{0}$ & Keterangan \\
\hline Responden & 0,19 & 0,15 & Normal \\
\hline
\end{tabular}

Berdasarkan Tabel 2 perhitungan uji normalitas akhir menggunakan nilai posttest diketahui setelah mencari harga Ltabel dari nilai kritis uji lilliefors dengan taraf signifikan $\mathrm{a}=$ $5 \%$ dan $n=36$ diperoleh Ltabel $=0,19$. Sehingga dapat disimpulkan bahwa LO $<$ Ltabel yaitu $0,15<0,19$ maka HO diterima. Hal ini berarti sampel berasal dari populasi yang berdistribusi normal. Langkah selanjutnya yaitu adalah melakukan uji $t$ adapun hasilnya dapat dilihat yaitu: 
Tabel 3. Daftar uji t-Pretest dan Posttest

\begin{tabular}{lll}
\hline Keterangan & Pretest & Posttest \\
\hline Rata-rata & 47,17 & 66,50 \\
Md & 19,33 & \\
$N$ & 36 & \\
$\sum x^{2} d$ & 24770,00 & \\
$\mathrm{~T}_{\text {hitung }}$ & 4,36 & \\
$\mathrm{~T}_{\text {table }}$ & 2,021 & \\
\hline
\end{tabular}

Berdasarkan Tabel 3 bahwa rata-rata siswa pada kondisi awal sebelum diberi perlakuan dengan menggunakan model problem solving nilai pretest sebesar 47,17 sedangkan rata-rata siswa sesudah diberi perlakuan dengan model problem solving sebesar nilai posttest sebesar 66,50. Dari data analisis uji t diperoleh thitung $=4,36$ selanjutnya dibandingkan dengan ttabel $=2,021$ dengan $\mathrm{db}=36-1$ pada taraf signifikan $5 \%$ hasil ini menunjukkan bahwa thitung > ttabel yaitu 4,36 > 2,021 maka Ha diterima dan $\mathrm{H} 0$ ditolak, sehingga dapat disimpulkan bahwa model problem solving dalam mata pelajaran Matematika materi pecahan efektif terhadap kemampuan pemahaman konsep operasi hitung pada siswa kelas V SD N Wonolopo 02 Semarang. Langkah selanjutnya yaitu melakukan uji $\mathrm{N}$-gain, untuk menghitung peningkatan pemahaman konsep operasi hitung siswa :

Tabel 4. Uji N-Gain

\begin{tabular}{llcl}
\hline Interval Gain & Kriteria & Frekuensi & Presentase \\
\hline $0,70 \leq \mathrm{g} \leq 1,00$ & Tinggi & 6 & $16,7 \%$ \\
$0,30 \leq \mathrm{g}<0,70$ & Sedang & 22 & $61,1 \%$ \\
$0,00<\mathrm{g}<0,30$ & Rendah & 4 & $11,1 \%$ \\
$\mathrm{~g}=0,00$ & Tetap & 0 & $0 \%$ \\
$-1,00 \leq \mathrm{g}<0,00$ & Terjadi Penurunan & 4 & $11,1 \%$ \\
Jumlah & & 36 & $100 \%$ \\
\hline
\end{tabular}

Berdasarkan data Tabel 4 diatas diperoleh hasil uji N-Gain melalui pretest dan posttest siswa kelas V SD N Wonolopo 02 Semarang pada materi perkalian dan pembagian pecahan. Dari jumlah siswa kelas $\mathrm{V} 36$ siswa, terdiri dari lima kriteria yaitu tinggi, sedang, rendah, tetap, dan terjadi penurunan. Pada kriteria tinggi terdapat 6 siswa dengan presentase $16,7 \%$, sedang terdapat 22 dengan presentase $61,1 \%$, rendah terdapat 4 siswa dengan presentase $11,1 \%$, dan terjadi penurunan terdapat 4 siswa dengan presentase $11,1 \%$. Jadi, dapat disimpulkan bahwa efektifitas kemampuan pemahaman konsep operasi hitung siswa kelas V SD N Wonolopo 02 Semarang mayoritas sedang.

Penelitian ini berjudul Penerapan Model Problem Solving Berbantu Media Kalkulator Ajaib Untuk Meningkatkan Kemampuan Pemahaman Konsep Operasi Hitung Pada Siswa. Penelitian ini dilaksanakan pada tanggal 18-21 februari 2019 di SD N Wonolopo 02 Semarang. SD N Wonolopo terletak pada jalan Raya Kuripan RT01/RW01 Wonolopo - Mijen Semarang. Penelitian ini dilaksanakan di SD N Wonolopo 02 Semarang tahun ajaran 2018/2019 pada kelas V yang berjumlah 36 siswa.

Sebelum penelitian dilaksanakan, peneliti melakukan studi pendahuluan dengan wawancara guru kelas $\mathrm{V}$ untuk mengetahui permasalahan yang ada dikelas dan diperoleh informasi bahwa proses belajar Matematika di kelas guru masih menggunakan metode tradisional ceramah dan diskusi belum menggunakan model pembelajaran, serta sesekali memanfaatkan media yang ada di lingkungan kelas. Hal tersebut mengakibatkan hasil belajar dan pemahaman konsep operasi hitung perkalian dan pembagian pecahan siswa rendah. Peneliti mempersiapkan rencana pelaksanaan pembelajaran yang akan disertai 
dengan model problem solving berbantu media kalkulator ajaib yang telah disetujui oleh guru kelas $\mathrm{V}$.

Pelaksanaan penelitian ini, di awal pertemuan siswa diberikan soal pretest untuk mengetahui hasil belajar siswa sebelum diberikan perlakuan. Tahap ini siswa belum diberikan oleh peneliti. Selesai mengerjakan pretest siswa baru diberikan perlakuan oleh peneliti. Perlakuan tersebut melalui proses pembelajaran selama 2 kali pertemuan. Di akhir perlakuan diberikan soal posttest untuk mengetahui hasil belajar siswa setelah menerima perlakuan oleh peneliti.

Model pembelajaran problem solving ini memliki keunggulan dalam mempelajari keterampilan dasar dan memperoleh yang diajarkan secara berdiskusi kelompok. Pelaksanaan pembelajaran dengan menggunakan model problem solving ini siswa diajak untuk berpikir bagaimana cara memecahkan masalah dengan menggunakan langkahlangkah yang diketahuinya.

Menurut Pepkin, 2004:1 (dalam Soimin, 2014: 135) Problem solving adalah suatu model pembelajaran yang melakukan pemusatan pada pengajaran dan keterampilan pemecahan masalah yang diikuti dengan penguatan keterampilan. Model problem solving membuat siswa lebih senang, tertarik dan lebih aktif dalam mengikuti proses pembelajaran.

Berdasarkan hasil data yang disajikan diatas, adanya peningkatan dalam kemampuan pemahaman konsep operasi hitung pada siswa disebabkan oleh penerapan model problem solving berbantu media kalkulator ajaib. Melalui penerapan model problem solving berbantu media kalkulator ajaib dalam pembelajaran matematika memudahkan siswa untuk memahami, menyusun rencana, dan melaksanakan rencana penyelesaian dalam proses menghitung perkalian dan pembagian pecahan. Selain itu, juga menumbuhkan antusiasme dan kerjasama, keaktifan siswa pada saat proses pembelajaran, menumbuhkan rasa ketertarikan siswa terhadap permasalahan yang sedang dihadapinya siswa menjadi lebih aktif, kreatif dan berpikir kritis dalam memecahkan masalah.

Berdasarkan uraian di atas, model pembelajaran Problem Solving berbantu media kalkulator ajaib dapat meningkatkan kemampuan pemahaman konsep operasi hitung pada siswa kelas V SD N Wonolopo 02 Semarang. Penerapan model problem solving berbantu media kalkulator ajaib untuk meningkatkan pemahaman konsep operasi hitung pada siswa dapat menambah motivasi siswa dalam belajar matematika, mengasah kemampuan siswa dalam memecahkan masalah dalam kehidupan sehari-hari, melatih kerjasama, mengembangkan kemampuan berpikir kreatif dan kritis, lebih bertanggung jawab dalam menyelesaikan tugas yang diberikan dan mengembangkan rasa ingin tahu siswa terhadap sebuah masalah.

\section{Simpulan dan Saran}

Berdasarkan analisis data hasil penelitian dan pembahasan dapat disimpulkan bahwa penerapan model problem solving berbantu media kalkulator ajaib efektif untuk meningkatkan kemampuan pemahaman konsep operasi hitung pada siswa. Setelah melakukan penelitian dengan menggunakan model problem solving berbantu media kalkulator ajaib terdapat peningkatan kemampuan pemahaman konsep operasi hitung pada siswa kelas V SD N Wonolopo 02 Semarang. Dilihat berdasarkan hasil perhitungan analisis rumus uji $t$ diperoleh $t_{\text {hitung }}=4,36$. Selanjutnya dikonsultasikan dengan $t_{\text {tabel }}$ dengan $\mathrm{db}=35$ dan taraf signifikansi $5 \%$ diketahui $t_{\text {tebael }}=2,021$ sehingga $t_{\text {hitung }}>t_{\text {tabel }}$ yaitu 4,36 $>2,021$. Dengan demikian $\mathrm{H}_{0}$ ditolak dan $\mathrm{H}_{\mathrm{a}}$ diterima. Oleh karena itu hipotesis yang berbunyi "Penerapan model problem solving berbantu media kalkulator ajaib efektif untuk meningkatkan kemampuan pemahaman konsep operasi hitung pada siswa kelas V SD N Wonolopo 02 Semarang". Serta berdasarkan hasil perhitungan analisis uji N-Gain terdapat peningkatan dalam hasil pretest dan posttest. Setelah dihitung dengan rumus N-Gain, nilai N-Gainnya tersebut diketahui sebesar 0,36 maka Interval Gain dalam kategori sedang 0,30 $\leq$ $\mathrm{g}<0,70$. Maka dapat disimpulkan bahwa efektifitas kemampuan pemahaman konsep operasi hitung siswa kelas V SD N Wonolopo 02 Semarang mayoritas sedang. 
Dari hasil penelitian, saran yang dapat diajukan adalah sebagai berikut: 1) Guru dapat menjadikan alternatif dan mempertimbangkan penggunaan model pembelajaran Probelm Solving berbantu media kalkulator ajaib dalam meningkatkan kemampuan pemahaman konsep operasi hitung pada materi perkalian dan pembagian pecahan mata pelajaran matematika, karena model pembelajaran ini mampu menarik perhatian siswa dan membuat siswa berfikir kritis dan kreatif dalam memahami dalam memecahkan masalah pecahan, 2) Guru dapat mengembangkan mode pembelajaran Problem Solving berbantu media kalkulator ajaib dengan teknik atau model pembelajaran lainnya sesuai dengan kebutuhan materi dan karakteristik siswa, dan 3) Bagi pembaca, penulis merekomendasikan model pembelajaran Problem Solving berbantu media kalkulator ajaib untuk diterapkan pada pembelajaran siswa Sekolah Dasar, karena model pembelajaran ini mampu menciptakan pembelajaran yang menyenangkan, mendapat partisipasi aktif dari siswa, dan dapat memecahkan permasalahan pecahan.

\section{Daftar Pustaka}

Arsyad, Azhar. 2016. Media Pembelajaran. Jakarta: PT Raja Grafindo Perseda.

Djamarah, Syaiful Bahri \& Aswan Zain. 2006. Strategi Belajar Mengajar. Jakarta: PT Rineka Cipta.

Hamdani. 2011. Strategi Balajar Mengajar. Bandung: CV Pustaka Setia.

Hidayat, T. (2014). Pengaruh Penggunaan LKS Berbasis Problem Solving Polya Materi Fluida Dinamis terhadap Kemampuan Menganalisis Peserta didik. Universitas Islam Negeri Syarif Hidayatullah.

Ikhwanuddin, Jaedund, A., \& Purwantoro, D. (2010). Problem Solving Dalam Pembelajaran Fisika Untuk Meningkatakan Kemampuan Mahasiswa Berpikir Analitis. Jurnal Kependidikan, 40(2), 215-230.

Jamhari. (2010). Penerapan Pendekatan Problem Solving dalam Meningkatkan Kemampuan Berfikir Kritis Peserta didik SMP Negeri 21 Palu pada Mata Pelajaran Biologi. Jurnal Biodidaktis, 3(2), 84.

Kokom, K. (2011). Penerapan Metode Pembelajaran Problem Solving Model Polya Untuk Meningkatkan Kemampuan Memecahkan Masalah Bagi Siswa Kelas IX J Di SMPN 3 Cimahi. In Prosiding seminar nasional penelitian, pendidikan dan penerapan MIPA Fakultas MIPA UNY (p. 1).

Kristiyawan, Arief. 2009. Peningkatan Pemahaman Konsep Luas Permukaan serta Volume Kubus dan Balok melalui Model Pembelajaran Aktif Tipe Snowball. Surakarta: Skripsi FKIP UMS. (Tidak Diterbitkan).

Soegeng, A.Y, dan Suharno, Agus. 2010. Statistika Inferensial.Semarang: IKIP PGRI Semarang Press.

Shoimin, Aris. 2014. 68 Model Pembelajaran Inovatif dalam Kurikulum 2013. Yogyakarta: ArRuzz Media.

Sudjana, M.A. 2005. Metoda Statistika. Bandung : PT Tarsito

Sugiyono. 2017. Metode Penelitian Pendidikan Pendekatan Kuantitatif, Kualitatif, dan R\&D. Bandung: Alfabeta. 
Susanto, Ahmad. 2016. Teori Belajar Pembelajaran Di Sekolah Dasar. Jakarta: Prenadamedia Group.

Trianto. (2007). Model Pembelajaran Terpadu dalam Teori dan Praktek. Jakarta: Prestasi Pustaka.

Trianto. (2011). Mendesain Model Pembelajaran Inovatif - Progresif. Jakarta: Jakarta Kencana.

Undang - Undang Republik Indonesia No. 20 Tahun 2003 Tentang Sistem Pendidikan Nasional. (2003). Retrieved from P-ISSN: 2303-288X E-ISSN: 2541-7207 Vol. 6, No.1, April http://setneg.go.id/index.php?option=com_perundangan\&id=323\&task=detail\&catid=1\& Itemid=42\&tahun=2003

Undang-Undang Nomor 20 Tahun 2003 tentang Sistem Pendidikan Nasional. 